Meta

Journal des tradlucteurs

Translators' Journal

\title{
Translating the Psalter
}

The Problem of Metre

\section{Watson Kirkconnell}

Volume 15, numéro 1, mars 1970

La traduction religieuse

URI : https://id.erudit.org/iderudit/003315ar

DOI : https://doi.org/10.7202/003315ar

Aller au sommaire du numéro

Éditeur(s)

Les Presses de l'Université de Montréal

\section{ISSN}

0026-0452 (imprimé)

1492-1421 (numérique)

Découvrir la revue

Citer cet article

Kirkconnell, W. (1970). Translating the Psalter: The Problem of Metre. Meta, 15(1), 10-17. https://doi.org/10.7202/003315ar d'utilisation que vous pouvez consulter en ligne.

https://apropos.erudit.org/fr/usagers/politique-dutilisation/ 


\section{TRANSLATING THE PSALTER
The Problem of Metre}

On July 13, 1965, Sister Marie-Joséfa (Miss Jeannine Bélanger) of the Grey Nuns of the Cross, Hull, Quebec, wrote to solicit my co-operation in producing a bilingual poetic version of the entire Psalter. She, as a graduate student in Hebrew and Greek, had already undertaken a French translation and had completed Books I-III (Psalms 1-89). Would I please supply an English verse translation, to be printed facing her French version, line for line and strophe for strophe, throughout the whole of a diglott edition? This could be a French-English, CatholicProtestant, doubly Canadian monument to national unity and religious ecumenicity.

My share of the joint enterprise is now completed, subject to thorough revision. The «translators' journal», META, has suggested that Miss Bélanger and I should prepare an article on the rationale of our work. My share of this assignment is to discuss the problem of Hebrew metre; my colleague is to expound the problem of the Hebrew strophe.

On my study table are the major tools for the translator's task : 1) the third edition (1945) of Kittel's Biblia Hebraica, with the Massoretic text checked by P. Kahle and with a copious critical apparatus for the Psalms (some 3,750 variant readings) supplied by P. Buhl, of Copenhagen; 2) the Greek of the fourth edition (1950) of Alfred Rahlfs' Septuagint; and 3) the Latin of the 1965 « editio emendatissima » of the Biblia Sacra Vulgatae Editionis, in which the Psalms are printed in three parallel Latin renderings, namely : a) the "Psalterium Gallicanum, » i.e., Jerome's translation from the Greek of the Septuagint in Origen's Hexapla; b) a new critical edition of Jerome's second version, which he made directly from the Hebrew; and c) an entirely new Latin version prepared, at the request of Pope Pius XII, by the professors of the Pontifical Biblical Institute, in Rome. Both the Septuagint and the Vulgate in the above editions are supplied with a generous critical apparatus. Latin and Greek were my original fields of university training and $\mathrm{I}$ had added Hebrew in 1914. For lexicographical use, I have my own copies of Gesenius' Hebrew and English Lexicon, the unabridged edition of Liddell 
and Scott's Greek Lexicon and the unabridged edition of Lewis and Short's Latin Dictionary. My own large library has been supplemented in this special enterprise by scores of volumes from the Acadia University Library.

But why should a couple of non-professionals (one of them a septuagenarian) undertake the task at all? Why did Miss Bélanger challenge me to match her French poetic version with one in English? And why did I so rashly accept the challenge?

On her side, she was working towards a doctorate in sacred letters (doctorat en Écriture sainte), with a thesis on the subject of Hebrew prosody and the tasks of the verse translator. My own half-century as a scholar had produced a score of volumes in verse translation, totalling over 4,000 pages, chiefly from Latin, Italian, Dutch, Magyar, Polish, Ukrainian and Icelandic. The idea of the diglott Psalter had come to her while reading a diglott anthology, The Quebec Tradition du Québec (University of Montreal, Faculty of Letters, 1946), in which prose and verse chosen by Dr. Séraphin Marion were printed facing, page by page, English versions made by myself. In the new enterprise, $A$ Psalter for Everyman/Les Psaumes pour tous, Miss Bélanger and I would go back independently to the Hebrew, Greek and Latin texts and would not translate from each other. I would, however, seek to adapt to English versifying her concepts of line and strophe in the Hebrew.

Apart from the challenge of verse translation, I was excited over the vast range of new Biblical knowledge that had opened up even during my life-time. The Lachish ostraca, the «Dead Sea Scrolls, » the insights gained from comparative Semitic philology (both Canaanite and Assyro-Babylonian), and the changes in the Massoretic text resulting from a shift from the Jacob Ben Chayyim text (16th century) back to a Ben Asher text (10th century) had all made their contribution. Excellent critical editions of the Septuagint and the Vulgate were now available. Archaeology and folklore had opened new windows. Protestants had felt compelled to produce a «Revised Standard Version $»$ and the Dominican Biblical School in Jerusalem had prepared a superb Bible de Jérusalem, presently issued also in English as The Jerusalem Bible. "Bliss was it in that dawn to be alive, » but to be old was to try to race the clock while the grey cells held out. But what of the countless times that I found myself a bewildered old goat, lost in the jungle thickets of textual criticism ? Quite frankly, I could then only commit myself to the scholarly guidance of the RSV, the Gelineau Psalter (Fontana Books) and, above all, the superbly annotated Jerusalem Bible.

But I am supposed to be analysing the nature of Hebrew metre. This, by the way, is easier to understand in the third edition of Kittel's Biblia Hebraica, where the text is printed stichometrically (i.e., with a separate line for each line of poetry) instead of being coagulated in large prose paragraphs. It was probably manuscripts of this latter sort that helped to confuse Saint Jerome as to the character of Hebrew verse. «Denique, » he wrote, «quid Psalterio canorius, quod in morem nostri Flacci et Graci Pindari, nunc iambo currit, nunc Alcaico personat, nunc Sapphico tumet, nunc semipede ingreditur ${ }^{1}$. The sad fact is that this is

1. J. P. Migne, ed., Patrologia Latina, XXVII, 223.

Vol. $15-\mathrm{N}^{\circ}$

Mars 1970 
just not so. Any attempt to find Greek and Latin quantitative measures in the scansion of Hebrew is doomed to immediate and total failure. There are too many long vowels and syllables in Hebrew to make a quantitative rhythm even faintly probable.

When we turn to the famous mediaeval Jewish poets, Jehudah Halevi and Solomon Ibn Gabirol, both of whom excelled in rhymed stanzas in the Arab style, we learn that they found no such prosody in ancient Hebrew poetry. Only accent, they said, was dominant and essential ${ }^{2}$.

According to Sir George Adam Smith, there is a prevalence in Hebrew words « of the harder heavier consonants, including a greater variety of gutturals, than Western alphabets contain. Much use is made of the explosive letters, and the doubled consonant exerts its full value, both for phonetic and for grammatical reasons... it is urgency more than beauty, emphasis more than melody, which strikes the ear as characteristic of Hebrew $\gg{ }^{3}$.

The first solid analysis of Hebrew prosody came from Robert Lowth ${ }^{4}$, of Oxford, in the 18th century. This was his recognition of three forms of parallelism, viz. : a) synonymous, b) antithetic, and c) synthetic :

a) Therefore the wicked shall not stand in the judgement, nor sinners in the congregation of the righteous. (Ps. 1, 5)

b) For the Lord regardeth the way of the righteous; but the way of the wicked shall perish. (Ps. 1, 6)

c) And I have anointed my king on Zion, my holy hill. (Ps. 2, 6)

In 1907, C. A. Briggs, in his commentary on the Psalter, listed three more types of parallelism, identified by earlier scholars, namely, emblematic (Ps. 103, 13), stairlike (Ps. 29, 5) and introverted or chiastic (Ps. 6, 9-11). Eight years later, George Buchanan Gray made a further real advance by distinguishing between two main types of parallelism : a) complete, with every term in the first member balanced by a term in the second (e.g. Ps. 83, 14) and b) incomplete, this latter with the missing term either compensated for (Ps. 59, 16) or left uncompensated (Ps. 84, 4). The most novel of the foregoing variants is «stairlike parallelism, » where a phrase is repeated in successive lines, like the treads on successive steps, as in Psalm 29, 1-2 :

Give to the Lord, ye sons of gods,

Give to the Lord, glory and strength,

Give to the Lord, the glory of his name.

Still another aspect of the same forms is the distinction sometimes made between an «external» parallelism of whole lines, as in the example just quoted, and « internal » parallelism within a single line, as in Psalm 74, 16 :

Thine is the day, yea, thine the night.

Another point sometimes stressed is that every unit, line or half-line, has a certain

2. Nina Salaman, ed. and tr., Selected Poems of Jehudah Halevi, Philadelphia, 1924, p. xxiii; «Thus Jehudah Halevi considered rhyme and metre as foreign to the Hebrew language and unnecessary to Hebrew poetry. "Cf. also Israel Zangwill, ed. and tr., Selected Religious Poems of Solomon Ibn Gabirol, Philadelphia, 1923, p. 1 : " The only indispensable element of Hebrew poetry was accent. In short what we now call free verse is closest to the old Hebrew form of expression. $\gg$

3. The Legacy of Israel, Oxford, 1927, p. 10-11.

4. Robert Lowth, Da sacra poësi Hebraeorum praelectiones academicae Oxonit habitae, 1753. 
consistency and independence by itself, and that true enjambement is therefore impossible ${ }^{5}$. A corollary of this is that the idea of parallelism involves at least two entities, in prosody as in mathematics ${ }^{6}$.

Behind the phenomenon of parallelism lies the very nature of Hebrew syntax, with its paratactic co-ordination of simple clause with simple clause, with few connectives except «and» and «then » and «but». There is thus no periodic architecture of subordination and hypotaxis, such as gives flexibility and subtlety to such languages as Greek and Latin - and even to German after die Humanisten began to model their prose style after Cicero. It was Hebrew's syntax, in other words, that imposed the parallelism of its poetic form. The same was true of Babylonian and Canaanite verse. Many of the Canaanite psalms from Ras Shamra are virtually identical in structure with the early Hebrew psalms.

If Hebrew syntax determined the «thought rhymes 》 of parallelismus membrorum, Hebrew accent and accidence determined the rhythm of the individual line or colon. Since in most Hebrew words the stress falls on the last syllable, it is clear that the rhythm is rising, or iambic-anapaestic. In Latin and Greek, on the contrary, the stress accent is recessive, falling on the third last syllable unless the second last is long (and then takes the stress). In other words, their line-rhythm tends to be dactylic, spondaic or trochaic, and the dactylic hexameter is admirably adapted to their poetry. Icelandic, in which inflections survive and in which there is sometimes an unstressed suffixed article, is naturally trochaic or dactylic. Modern English, which has lost nearly all its inflexional suffixes and uses many prepositions and articles before the noun, is by nature iambic.

At this point, Sigmund Mowinckel, the Norwegian scholar, would ask us to sharpen our definitions : "[Hebrew] metre consists of the repetition of the same rhythmical sequence; a single line has its rhythm, as have all clauses of the language, but it has no metre $^{7} \gg$.

The irreducible, basic unit is the foot, usually consisting of one or more unstressed syllables followed by a stressed syllable. Much the commonest foot is the iamb. The shortest line, which we may call a « half-verse will consist of four accented feet (two-plus-two). In the commonest metre, two such four-beat lines (or cola, or half-verses) follow each other to form a larger unit, the «bicolon» or « verse. » This is the «mashal metre » or « wisdom poetry metre. $\gg$ An example, from Psalm 21, 3, is

ta'awath libbo nathatta lo

wa'aresheth sephathaiw bal-mana'eta.

Another very common metre is the qinah, or dirge measure, or elegiac measure, where the first verse-member in a colon has three stresses and the second has two stresses. An example, from Psalm 27, 1b, is

Yahweh maioz-hayyay mimmi ephadh

A somewhat rarer variant is a $2: 3$ line.

Still another mode of metrical expansion is by triplication :

a) The simplest method is to add one stressed foot to each member of the colon, producing three feet in each. This is much the commonest metre in the

5. W.C.E., Oesterley, The Psalms, 1962, p. 27.

6. Ibid.

7. Sigmund Mowinckel, The Psalms in Israel's Worship, Oxford, 1962, vol, II, p. 168.

Vol. $15-\mathrm{N}^{\circ} 1$ 
Psalms. It represents a progressive development beyond the mashal line (2:2) and the qinah $(3: 2$ or $2: 3)$ to an even $3: 3$.

b) A much rarer version is a third term within the colon itself (i.e. $2: 2: 2$ or $3: 3: 3)$.

c) Still rarer is a seven-foot colon (e.g., $2: 2: 3$ or $3: 2: 2$ ).

d) We may also note the occasional occurrence of a «tricolon», i.e., a sequence of three four-footed cola. Mowinckel suggests ${ }^{8}$ that this is probably a bob-tailed version of a double bicolon, the latter being the basic strophe (or stanza) of Hebrew poetry. Beyond that again, as Miss Bélanger will point out, are strophes consisting of greater numbers of bicola.

Many authorities, and especially E. Sievers, ascribe to Hebrew metre a measure of irregularity that is quite unnatural. Sievers, for example, would regard most Hebrew poems as an irregular mingling of all sorts of metrical bicola (mashal, qinah, and the like) in any sort of order. But we must not be too rigid about our rules. In English, for example, which is almost as emphatically accentual as Hebrew, there is a completely normal readiness in the iambic pentameter (or blank verse line) to substitute feet other than the iamb in order to adapt the sound of the line to the thought or emotion of its content. The whole secret of good blank verse, in fact, lies in the modulation of the feet and of the caesura. Take, for example, these lines from Tennyson's Geraint and Enid:

But while the sun yet beat a dewy blade,

The sound of many a heavily galloping hoof

Smote on her ear, and turning round she saw

Dust, and the points of lances bicker in it ${ }^{9}$.

The opening line is normal, a succession of iambs. In the second, the replacement of three such feet with dactyls gives the effect of galloping, while the trochees that begin lines three and four give heavy emphasis to what is suddenly heard and seen. Also contributory to these effects is the lack of any pause within line two or at the end of it, while the unusual pause after «Dust» reproduces the effect of Enid's surprised glance. The tribrach at the end of line four makes the very line bicker. Similarly in Hebrew metre we need to realize that certain variations, such as $2: 2$ with $3: 2$ and $2: 2: 2$ with $3: 3$, are as normal as the standard variations in English blank verse.

Some conflict of opinion also prevails as to whether the same measure (e.g., mashal or qinah) normally persists throughout an entire psalm. The bulk of opinion ${ }^{10}$ today believes in such regularity. Most psalms were made for singing, and this fact makes for uniformity of metre. English hymns would be rather frustrating if the tune changed with every stanza! We need to remember, moreover, the age of the psalms and the probability that many of them have not reached us in their original form. We cannot even be certain as to the older pronunciation of the language, at a stage, for example, when original short vowels had not yet been reduced to shewas or even lost entirely.

But in what English verse-forms should we seek to translate the Hebrew psalms ? Certain principles may be suggested :

8. Mowinckel, op. cit., vol. II, p. 165 ad finea.

9. Roman type mine.

10. Oesterley, op. cit., p. 31; cf. also Mowinckel, op. cit., p. 174. 
a) Since parallelism, or "thought rhyme, » is basic to the Hebrew, we ought, perhaps, to render each line of Hebrew verse by a line of English verse, with a marked end-pause.

b) In the Scottish Psalter, «long measure » (8.8.8.8.) is roughly equivalent to the Hebrew mashal metre, and «common measure» (8.6.8.6.) to the Hebrew qinah metre. Incidentally, common measure is also familiar as English ballad metre.

c) Since Hebrew is more laconic than English, i.e., requires fewer syllables to express a given quantum of meaning, the English verse-line may well be longer than the original Hebrew line. French, as a language, is still less laconic in expression. A syllable-count of the Gospel According to Saint Matthew gives 29,000 syllables for English and 36,000 for French ${ }^{11}$. It is noteworthy that while English heroic verse uses the iambic pentameter line, French uses the Alexandrine.

d) Since the natural rhythm of Hebrew is rising (iambic or anapaestic or both), so iambic verse, with an occasional anapaest, would be a natural equivalent in English.

e) Since the overwhelming majority of English hymns are rhymed, we ought probably to plan on rhymed translations from the unrhymed Hebrew. Quite a different system is involved in the plainsong of the Roman Church, which is designed for use with non-metrical prose translations of the Psalms.

Finally, we may gain some idea of the dimensions of our problem by tracing a random verse (Ps. 27, 1) through a long succession of versions. In each case, except $\mathrm{e}$ ) and $\mathrm{h}$ ), the same pattern of clauses has been reproduced :

a) HEBREW, MASSORETIC TEXT

Yahweh 'ori we-yishi

mimmi ira'?

Yahweh ma'oz-hayyay

mimmi ephadh?

(iambic bicolon, 21 syllables)

b) GREEK, SEPTUAGINT

Kyrios phôtismos mou kai sôtêr mou:

tina phobêthêsomai?

Kyrios hyperaspistês tês zôês mou;

apo tinos deiliasô?

(prose, 37 syllables)

c) VULGATE, PSALTERIUM GALLICANUM

Dorninus illuminatio mea et salus mea, quem timebo?

Dominus protector vitae meae, a quo trepidabo?

(prose, 36 syllables)

d) BOOK OF COMMON PRAYER (1552)

The Lord is my light and my salvation; whom then shall I fear:

The Lord is the strength of my life; of whom then shall $I$ be afraid?

(prose, 30 syllables)

11. Cf. Watson Kirkconnell, "Linguistic Laconicism", American Journal of Philology, XLVIII, 1, p. 34-37. 
e) SIR PHILIP SIDNEY (before 1586)

The shining Lord he is my light,

The strong God my salvation is:

Who shall be able me to fright?

This Lord with strength my life doth blisse

And shall $I$ then

Feare might of men?

(irregular lyric, 36 syllables)

f) KING JAMES VERSTON (1611)

The Lord is my light and my salvation; whom shall 1 fear?

The Lord is the strength of my life; of whom shall 1 be afraid?

(prose, 27 syllables)

g) TREMELIIUS AND JUNIUS (1624)

Jehova lux mea et salus mea est, a quo timerem?

Jehova robur vitae meae est,

a quo expavescerem?

(prose, 34 syllables)

h) ARTHUR JOHNSTON (1637)

Cur ego formidem? Lux et spes certa salutis

Est Deus et vitae firma columna meae.

(elegiac couplet, 27 syllables)

i) SCOTTISH PSALTER (1650)

The Lord's my light and saving health;

Who shall make me dismayed?

My life's strength is the Lord; of whom

Then shall $I$ be afraid?

(qinah metre, rhymed, 26 syllables)

j) GELINEAU PSALTER (1963)

The Lord is my light and my help; whom shall I fear?

The Lord is the stronghold of my life; before whom shall I shrink?

(qinah metre, unrhymed, 25 syllables)

k) NEW PAPAL VERSION (1965)

Dominus lux mea et salus mea: quem timebo?

Dominus praesidium vitae meae: a quo trepidabo?

(prose, 32 syllables)

1) JERUSALEM BIBLE (1966)

Yahweh is my light and my salvation, whom need I fear?

Yahweh is the fortress of my life, of whom should I be afraid?

(qinah metre, unrhymed, 24 syllables) 
m) JEANNINE BÉLANGER (1966)

Ma lumière, c'est le Seigneur, aussi, que craindre? $N$ 'ai-je en Lui mon sauveur,

le rempart de mes jours? Qui pourrait bien m'atteindre sous les soins du Seigneur?

(36 syllables)

n) WATSON KIRKCONNELL (1969)

Jehovah is my light, my help in strife : What fears can me offend?

Jehovah is the stronghold of my life: Whom need $I$ apprehend?

(24 syllables)

WATSON KIRKCONNELL 